\title{
Assessment of Methylobacterium oryzae CBMB20 aggregates for salt tolerance and plant growth promoting characteristics for bio-inoculant development
}

\author{
Mak Chanratana ${ }^{1 \dagger}$, Gwang Hyun Han ${ }^{1 \dagger}$, Aritra Roy Choudhury', Seshadri Sundaram ${ }^{1,2}$, Md. Abdul Halim',
} Ramasamy Krishnamoorthy ${ }^{3}$, Yeongyeong Kang ${ }^{1}$ and Tongmin Sa ${ }^{1^{*}}$ (i)

\begin{abstract}
Salinity is one of the major factors contributing to the loss of crop productivity and thereby impacting livelihood of people in more than 100 countries of the world and the area of land affected by salinity is increasing day by day. This will worsen due to various factors such as drought that might result in high soil salinity. Use of plant growth promoting rhizobacteria is one of the promising eco-friendly strategies for salinity stress management as part of sustainable agricultural practices. However, it requires selecting rhizobacteria with good survivability and adaptation to salt stress. In this study we report aggregation of Methylobacterium oryzae CBMB20 cells grown in media containing high C/N ratio (30:1) than in media containing low C/N ratio (7:1). Aggregated Methylobacterium oryzae CBMB20 cells exhibited enhanced tolerance to UV irradiation, heat, desiccation, different temperature regimes, oxidative stress, starvation and supported higher population in media. Poly- $\beta$-hydroxybutyrate accumulation, exopolysaccharide production, proline accumulation and biofilm formation were good at $100 \mathrm{mM}$ salt concentration with good microbial cell hydrophobicity at both 50 and $100 \mathrm{mM}$ than other concentrations. Both the aggregated and non-aggregated cells grown under 0-200 mM salt concentrations produced IAA even at $200 \mathrm{mM}$ salt concentration with a peak at $100 \mathrm{mM}$ concentration with aggregated cells producing significantly higher quantities. ACC deaminase activity was observed in all $\mathrm{NaCl}$ concentrations studied with gradual and drastic reduction in aggregated and non-aggregated cells over increased salt concentrations.
\end{abstract}

Keywords: Methylobacterium oryzae CBMB20, Salt stress, C/N ratio, Proline, PHB, EPS

\section{Introduction}

Soil salinity adversely affects the livelihood of people in more than 100 countries, as they occupy about 831 million ha (Mha) all over the world. Out of this area, 397 Mha (47.8\%) are saline, while 434 Mha (52.2\%) are sodic. On the regional scale, Asia, the Pacific and Australia together have the largest (30\%) salt affected land (Sharma

\footnotetext{
*Correspondence: tomsa@chungbuk.ac.kr

† Mak Chanratana and Gwang Hyun Han contributed equally to this work

${ }^{1}$ Department of Environmental and Biological Chemistry, College

of Agriculture, Life and Environment Sciences, Chungbuk National

University, Cheongju, Chungbuk 361-763, Republic of Korea

Full list of author information is available at the end of the article
}

and Chaudhari 2012). It is claiming about 3 hectares of arable land from conventional crop farming every minute. Microbial inoculants play a vital role for alleviation of salt stress for crop growth and developments. Plant growth-promoting bacteria (or PGPB) belong to a beneficial and heterogeneous group of microorganisms found in the rhizosphere and are capable of enhancing the growth of plants and protecting them from diseases and alleviate abiotic stresses. The mechanisms by which they stimulate plant growth involve the availability of nutrients originating from genetic processes, such as biological nitrogen fixation, phosphate solubilization, stress alleviation through the modulation of ACC deaminase 
expression, and production of phytohormones and siderophores, among several others (Glick 2012; Souza et al. 2015).

Identification and development of stress-tolerant microbial strains associated with the roots of agronomic crops can lead to improved fertility of salt-affected soils (Maheshwari 2012). However, development of bio-inoculants for agricultural usage requires strategies that can prevent the rapid decline of inoculant populations and extend the shelf life of formulations for a longer period both under storage conditions (Bashan et al. 2014) and after inoculation into soil. It is desirable to study the physiological state of bio-inoculants (cell growth, physiological characteristics etc.), and its role in the survival of the inoculants under stress environment (Catroux et al. 2001; Kadouri et al. 2005). Various biochemical characters of bio-inoculants include sporulation (González-Pastor 2011); aggregation/floc cells (Burdman et al. 2000); accumulation of exopolysaccharide (EPS) (Bahat-Samet et al. 2004), poly- $\beta$-hydroxybuterate (PHB), and biofilm formation (Kadouri et al. 2003). These traits either individually or in combination can enhance the survival of inoculants against various stress conditions. Aggregation of inoculants has been reported to be a promising approach for large-scale production and easy harvest from the culture medium (Neyra et al. 1997). Flocculated or aggregated cells Azospirillum sp. has been reported to maintain high survival rate during long periods of storage, and even on the spermoplane and spermosphere of plants (Joe and Sivakumar 2009; Joe et al. 2010, 2012).

Methylobacterium sp. are capable of using various carbon sources including methanol, methylamine and can colonize the phyllosphere and the rhizosphere of plants (Idris et al. 2004; Omer et al. 2004; Whipps et al. 2008; Madhaiyan et al. 2009). In this study, aggregated $M$. oryzae CBMB20 grown in ammonium mineral salt (AMS) medium with high $\mathrm{C} / \mathrm{N}$ ratio was studied for their endurance under various abiotic stresses. Additionally, production of proline, IAA, ACC deaminase, Poly- $\beta$ hydroxybutyrate (PHB) accumulation, exopolysaccharide (EPS) production, and biofilm formation under salt stress conditions were also evaluated.

\section{Materials and methods}

\section{Methylobacterium oryzae CBMB20 growth in high and low} $\mathrm{C} / \mathrm{N}$ ratio

A modified protocol of Burdman et al. (1998) was used to make the high and low $\mathrm{C} / \mathrm{N}$ ratio media. $10 \mathrm{ml}(8.00$ $\log \mathrm{CFU} \mathrm{ml}{ }^{-1}$ ) of secondary culture of Methylobacterium oryzae CBMB20 (DSM $18207^{\mathrm{T}}$ ) was transferred to sterile high $\mathrm{C} / \mathrm{N}$ and low $\mathrm{C} / \mathrm{N}$ medium with sodium succinate used as the sole carbon source (Madhaiyan et al. 2009). Flasks containing $100 \mathrm{ml}$ of culture media was incubated in shaker at $180 \mathrm{rpm}$ and maintained at $30{ }^{\circ} \mathrm{C}$ for $72 \mathrm{~h}$. The bacterial suspension equivalent to $9.00 \log \mathrm{CFU} \mathrm{ml}{ }^{-1}$ was used in all subsequent experiments.

\section{Evaluation of growth and biochemical characteristics of cells}

Estimation of the bacterial cell dry weight and cell hydrophobicity and aggregation were carried out following standard protocol described earlier (Grimaudo and Nesbitt 1997; Joe et al. 2013; Kumar et al. 2014; Perpetuini et al. 2017). To measure dry cell weight (DCW), centrifuge tubes were dried to constant weight and $10 \mathrm{ml}$ of bacterial culture was harvested and washed with saline solution. The pooled samples were kept in pre-weighed centrifuge tubes and dried in the oven at $80^{\circ} \mathrm{C}$ overnight. Dry weight was recorded as $\mathrm{mg}$ per $\mathrm{ml}$ of medium $(\mathrm{mg} /$ $\mathrm{ml}$ ).

The adhesiveness of bacteria to xylene gave the idea about cell surface hydrophobicity or hydrophilicity, while the values obtained from the other two solvents. i.e., ethyl acetate and chloroform were regarded as a measure of acidic (electron acceptor) or basic (electron donor) characteristics of bacteria, respectively. For aggregation studies, $1 \mathrm{ml}$ of bacterial culture was added to $10 \mathrm{ml}$ aggregation buffer which consisted $20 \mathrm{mM}$ Tris- $\mathrm{HCl}$ (pH 7.8), $0.01 \mathrm{mM} \mathrm{MgCl} 2,0.1 \mathrm{M} \mathrm{NaCl}$, and $0.02 \%$ sodium azide.

Bacterial exopolysaccharide (EPS) was estimated by phenol-sulfuric acid method using glucose as standard (Albalasmeh et al. 2013). Biofilm formation was estimated following Djordjevic et al. (2002) and Merritt et al. (2005).

Poly- $\beta$-hydroxybutyrate (PHB) accumulation within the cells was analyzed by Gas Chromatograph (GC $6890 \mathrm{~N}$, Agilent Inc., HP-5 column, $30 \mathrm{~m} \times 320 \mu \mathrm{m} \times 0.25 \mu \mathrm{m})$ equipped with flame ionization detector (FID). Briefly, $10-20 \mathrm{mg}$ of dry cells were added into $10 \mathrm{ml}$ screw cap test tubes with $2 \mathrm{ml}$ chloroform and $2 \mathrm{ml}$ acidic methanol (2.8 $\mathrm{M} \mathrm{H}_{2} \mathrm{SO}_{4}$ in methanol). One gram of benzoic acid was dissolved in 11 methanol and used as an internal standard. Methanolysis was performed at $100{ }^{\circ} \mathrm{C}$ for $3.5 \mathrm{~h}$ in an oven and mixed by shaking every $30 \mathrm{~min}$. After cooling at room temperature, $1 \mathrm{ml}$ of distilled water was added into the tubes; the mixture was shaken vigorously for $1 \mathrm{~min}$ and kept for about $30 \mathrm{~min}$ for phase separation. One microliter of the sample was injected and nitrogen (99.99\%) was used as carrier gas with a constant flow rate of $20 \mathrm{ml} / \mathrm{min}$. The GC separation was performed under following conditions: oven temperature programmed to increase from $60^{\circ} \mathrm{C}(5 \mathrm{~min})$ to $180^{\circ} \mathrm{C}(5 \mathrm{~min})$ at a heating rate of $4{ }^{\circ} \mathrm{C} / \mathrm{min}$. The injector and detector temperatures were kept at 230 and $280{ }^{\circ} \mathrm{C}$, respectively (Kumar et al. 2014). All the analyses were conducted in triplicates. 
Abiotic stress endurance of $M$. oryae CBMB20

Methylobacterium oryae CBMB20 bacterial culture grown under high $\mathrm{C} / \mathrm{N}$ and Low $\mathrm{C} / \mathrm{N}$ medium were harvested at $72 \mathrm{~h}$ and washed twice with saline solution and were subsequently used in all the following experiments. All tests were performed in triplicates.

Physical stress was applied by irradiation with ultraviolet light. Ultraviolet irradiation resistance, survivability under desiccation and the starvation experiment with different salt concentrations $(0,50,100,150$ and $200 \mathrm{mM}$ $\mathrm{NaCl}$ ) were performed pursuant to (Kadouri et al. 2003; Zhao et al. 2007; Wang et al. 2009), respectively.

Resistance to ultraviolet irradiation was tested by placing $20 \mathrm{ml}$ of cells in Petri dishes and exposing them to short wavelength UV light $(254 \mathrm{~nm})$ using the ultraviolet lamp for $120 \mathrm{~s}$ (Zhao et al. 2007). Survival of cells under desiccation was tested by placing $100 \mu \mathrm{l}$ of bacteria on slides. The slides were air dried in a laminar flow at a constant air flow of $0.45 \mathrm{~m} / \mathrm{s}$ for $60 \mathrm{~min}$. The slides were kept at $30{ }^{\circ} \mathrm{C}$ for $30-180$ min after desiccation under laminar flow. Later the cells were suspended in potassium phosphate buffer (0.06 M, pH 6.8) and plated on nutrient agar (Kadouri et al. 2003). The starvation experiment was done by incubating $50 \mathrm{ml}$ of bacterial culture in M9 medium without carbon source on a shaker at $180 \mathrm{rpm}$ for 30 days. Bacterial population $\left(\mathrm{cfu} \mathrm{ml}^{-1}\right)$ was subsequently determined every 5-day interval (Wang et al. 2009).

Aliquots of bacterial culture $(100 \mu \mathrm{l})$ were evenly spread on $90 \mathrm{~mm}$ Petri dishes containing AMS agar. Simultaneously, $25 \mu \mathrm{l}$ of $\mathrm{H}_{2} \mathrm{O}_{2}(3.0 \%)$ was placed on $13 \mathrm{~mm}$ Whatman discs and left to air dry for $15 \mathrm{~min}$. A single disc was placed in each petri dish and incubated at $30{ }^{\circ} \mathrm{C}$ for $72 \mathrm{~h}$. The size of the halo zone around the disc was taken as a measure of the bacterial sensitivity against $\mathrm{H}_{2} \mathrm{O}_{2}$ (Kadouri et al. 2003).

For heat stress, bacterial cells ( $1 \mathrm{ml}$ in centrifuge tube) were incubated in a water bath at different temperatures $\left(30,40,45,48\right.$ and $50{ }^{\circ} \mathrm{C}$ ) for $10 \mathrm{~min}$. For cold stress, cells were incubated at $4{ }^{\circ} \mathrm{C}$ and taken out every $24 \mathrm{~h}$ till $192 \mathrm{~h}$ and the viability was studied by plating (Zhao et al. 2007).

\section{Cell viability of $M$. oryzae CBMB20 in glycerol during storage}

Bacterial cells were harvested by centrifugation at $10,000 \times g$ at $4{ }^{\circ} \mathrm{C}$ for $5 \mathrm{~min}$, then washed twice with saline solution and adjusted to a final concentration of bacteria $\left(9.00 \log \mathrm{CFU} \mathrm{m}{ }^{-1}\right)$ in $2 \%(\mathrm{v} / \mathrm{v})$ glycerol solution. The liquid form of inoculants was incubated at $4{ }^{\circ} \mathrm{C}, 30{ }^{\circ} \mathrm{C}$, $40{ }^{\circ} \mathrm{C}$ and $50{ }^{\circ} \mathrm{C}$ for 3 months. One milliliter sample was withdrawn at specific time intervals (30 days), and the number of viable cells were estimated by the plate count method (CFU ml ${ }^{-1}$ ) in a series of dilution (in $0.85 \%$ saline) and then plated on a nutrient agar plate.

\section{Evlauation of $M$. oryzae CBMB20 under salt stress}

The sensitivity of cells to osmotic stress was determined by exposing the bacterial cells to $50,100,150$ and $200 \mathrm{mM}$ of $\mathrm{NaCl}$ on a shaker at $180 \mathrm{rpm}$ for $72 \mathrm{~h}$ and incubating them at $30{ }^{\circ} \mathrm{C}$ (Zhao et al. 2007). Free proline accumulation was determined as described earlier (Sandhya et al. 2010). Briefly, $10 \mathrm{ml}$ of bacterial suspension was harvested by centrifugation at $3000 \times g$ for $5 \mathrm{~min}$. The cell pellet was suspended in $70 \%$ ethanol and boiled at $60{ }^{\circ} \mathrm{C}$ in a water bath for $45 \mathrm{~min}$. The suspension was centrifuged at $10,000 \times g$ for $15 \mathrm{~min}$ and the supernatant was estimated for proline content (Bates et al. 1973; Mahipant et al. 2017). Plant growth promoting characteristics like production of indole-3 acetic acid (IAA) in the presence and absence of tryptophan (Bano and Musarrat 2003) and 1-aminocyclopropane-1-carboxylate (ACC) deaminase activity by growing the bacteria on DF minimal salt medium (Li et al. 2011) amended with $3 \mathrm{mM} \mathrm{ACC}$ as nitrogen source (Penrose and Glick 2003) with different concentrations of salt $(0,50,100,150$ and $200 \mathrm{mM} \mathrm{NaCl})$ were also studied.

\section{Statistical analysis}

All data were normalized and subjected to analysis of variance (ANOVA). Significant differences among means were tested with Duncan's Multiple Range Test (DMRT) at $\mathrm{P}<0.05$ using SAS Version 9.1.3 service pack 4 (designed by SAS Institute Inc., Cary, North Carolina, USA) for all data in the experiments.

\section{Results}

Growth of $M$. oryzae CBMB20 under high and low $\mathrm{C} / \mathrm{N}$ ratio Growth and population of $M$. oryzae CBMB20 was more in high $\mathrm{C} / \mathrm{N}$ ratio medium than the low $\mathrm{C} / \mathrm{N}$ ratio medium (Table 1). The population increased both in terms of cfu ml $\mathrm{m}^{-1}$ and cell dry weight compared to low $\mathrm{C} / \mathrm{N}$ medium. Interestingly the bacterial cells grown in high $\mathrm{C} / \mathrm{N}$ ratio medium showed aggregation of cells evidenced by the significantly higher cell aggregates. The formations of cell aggregation was visible within $24 \mathrm{~h}$ of culture. In consonance with the population, the poly-hydroxybutyrate (PHB) content was twofold higher in the aggregated $M$. oryzae CBMB20 cells grown in high $\mathrm{C} / \mathrm{N}$ ratio medium. Similarly, the exopolysaccharide (EPS) analyzed was also threefold higher. Consequently, the biofilm formation in aggregated cells registered 35\% enhancement compared to their non-aggregated counterparts grown in low $\mathrm{C} / \mathrm{N}$ media. 
Table 1 Cell growth and physiological characteristics of aggregated and non-aggregated M. oryzae CBMB20 cells

\begin{tabular}{llllllll}
\hline Treatment & Population $^{\mathbf{a}}$ & Dry weight $^{\mathbf{b}}$ & PHB production $^{\mathbf{c}}$ & EPS production $^{\mathbf{d}}$ & Biofilm formation $^{\mathbf{e}}$ & Aggregation $^{\mathbf{f}}$ & Hydrophobicity $^{\mathbf{f}}$ \\
\hline High C/N & $8.48 \pm 0.028^{\mathrm{a}}$ & $6.51 \pm 0.22^{\mathrm{a}}$ & $0.53 \pm 0.26^{\mathrm{a}}$ & $0.64 \pm 0.04^{\mathrm{a}}$ & $0.294 \pm 0.0^{\mathrm{a}}$ & $35.96 \pm 0.33^{\mathrm{a}}$ & $40.02 \pm 0.27^{\mathrm{a}}$ \\
Low C/N & $7.92 \pm 0.027^{\mathrm{b}}$ & $3.45 \pm 0.11^{\mathrm{b}}$ & $0.23 \pm 0.40^{\mathrm{b}}$ & $0.20 \pm 0.02^{\mathrm{b}}$ & $0.189 \pm 0.0^{\mathrm{b}}$ & $22.37 \pm 3.16^{\mathrm{a}}$ & $11.65 \pm 0.44^{\mathrm{b}}$ \\
\hline
\end{tabular}

a $\log \mathrm{CFU} \mathrm{ml} \mathrm{m}^{-1}$

${ }^{b} \mathrm{mg} \mathrm{ml}^{-1}$

c $\mathrm{mg} \mathrm{PHB} \mathrm{g}^{-1}$ cell dry weight

${ }^{d} \mathrm{mg} \mathrm{EPS}^{-1}$ cell dry weight

${ }^{\mathrm{e}}$ Amount of dye (crystal violet) used to stain was quantified by measuring at $\mathrm{OD}_{595 \mathrm{~nm}}$

f Percentage (\%)

\section{Stress endurance of $M$. oryzae CBMB20}

Exposure to different stress conditions like UV, desiccation and starvation stress revealed that aggregated $M$. oryzae CBMB20 was more tolerant than non-aggregated cells (Fig. 1). When bacteria were exposed to short UV wavelength at $254 \mathrm{~nm}$, the population of non-aggregated
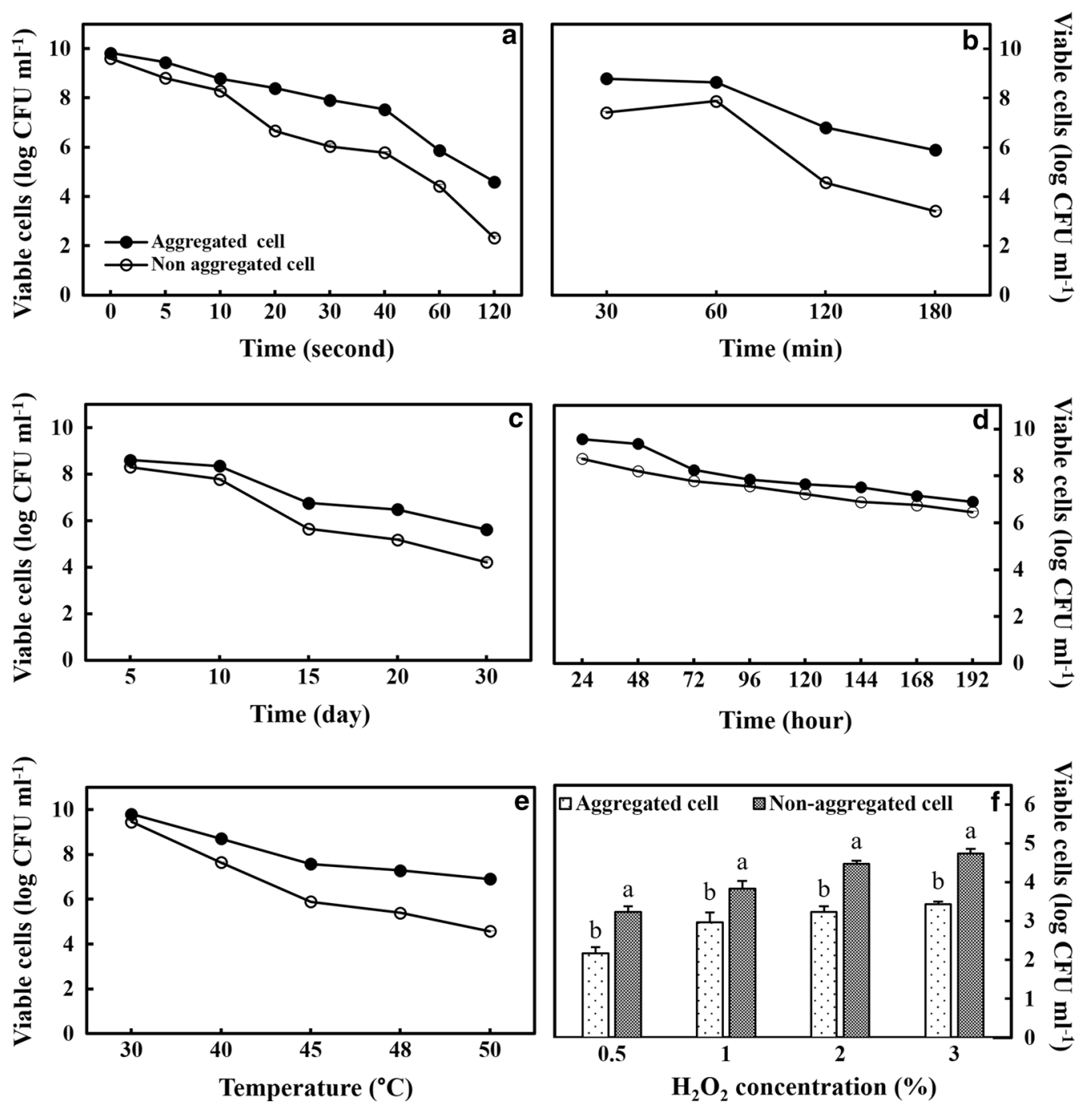

Fig. 1 The impact of various stresses on the growth of M. oryzae CBMB20. a UV irradiation. b Desiccation. $\mathbf{c}$ Starvation and $\mathbf{d}$ cold $\left(4^{\circ} \mathrm{C}\right)$. e Heat $\left(30-50{ }^{\circ} \mathrm{C}\right)$, f oxidative $\left(\mathrm{H}_{2} \mathrm{O}_{2}\right)$. All data represents mean $\pm \mathrm{SE}$ of three replicates and differences between means analyzed using DMRT test $(P \leq 0.05)$ 
of bacterial cells dramatically decreased to less than $20 \%$ survival within $120 \mathrm{~s}$ of UV treatment (Fig. 1). Under desiccation stress, the survival rate of non-aggregated cells declined to $30 \%$ compared to more than $60 \%$ survival of aggregated cells (Fig. 1). Besides that, when $M$. oryzae CBMB20 was exposed to starvation stress, aggregated cells showed higher survival than non-aggregated cells (Fig. 1).

When incubated at different temperatures, the aggregated cells survived better at 4,30 and $40{ }^{\circ} \mathrm{C}$ after 3 months of storage compared to non-aggregated cells (Fig. 2). However, further raising the temperature to $50{ }^{\circ} \mathrm{C}$ showed a slow but gradual and uniform decline in survival of both aggregated as well as non-aggregated cells. It was also observed that the difference becomes distinct among both the physiological forms immediately after 5 days of incubation (Fig. 2). However, storage at $4{ }^{\circ} \mathrm{C}$ over $192 \mathrm{~h}$ did not show major difference among the both the forms.

Aliquots of bacterial culture $(100 \mu \mathrm{l})$ were evenly spread on $90-\mathrm{mm}$ Petri dishes containing AMS agar. Simultaneously, $25 \mu \mathrm{l}$ of $\mathrm{H}_{2} \mathrm{O}_{2}(3.0 \%)$ was placed on 13-mm Whatman discs and left to air dry for $15 \mathrm{~min}$. A single disc was placed in each petri dish and incubated at $30{ }^{\circ} \mathrm{C}$ for $72 \mathrm{~h}$. The size of the halo zone around the disc was taken as a measure of the bacterial sensitivity against $\mathrm{H}_{2} \mathrm{O}_{2}$ (Kadouri et al. 2003). When their growth was studied in the presence of $\mathrm{H}_{2} \mathrm{O}_{2}$, the non-aggregated cells were more sensitive to $0.5-3.0 \% \mathrm{H}_{2} \mathrm{O}_{2}$ than aggregated cells that showed around $22-33 \%$ tolerance to the increasing concentrations of $\mathrm{H}_{2} \mathrm{O}_{2}$ (Fig. 1).

\section{Effect of salt stress on M. oryzae CBMB20}

Salt stress $(0-200 \mathrm{mM}$ of $\mathrm{NaCl})$, in general, showed a negative correlation with the survival of the bacteria (Fig. 3). Here, both the forms i.e. aggregated and non-aggregated cell types showed sensitivity to higher salt concentration. While both cell types were able to grow well in optimal salt concentration at $100 \mathrm{mM} \mathrm{NaCl}$, aggregated cells were quite resistant to salt stress than non-aggregated cells with better growth. Even with prolonged exposure to salt stress the survival was quite significantly higher in aggregated cells. This could be attributed to increased EPS production, biofilm formation and proline accumulation in the aggregated cells (Fig. $3 d-f)$. While the aggregated cells continued to show cell aggregation, higher cell hydrophobicity, EPS production, biofilm formation, PHB content and proline content in cells at 50 and $100 \mathrm{mM}$ salinity, the values declined at 150 and $200 \mathrm{mM} \mathrm{NaCl}$. Compared to non-aggregated cells, up to two to threefolds EPS production was observed with increasing salt concentration till $100 \mathrm{mM} \mathrm{NaCl}$.

When the both forms were studied for plant growth promotion traits, IAA production was higher in aggregated cells up to $100 \mathrm{mM}$ salinity. Though the trend was similar in non-aggregated cells, at $200 \mathrm{mM} \mathrm{NaCl}$ concentration the IAA levels declined drastically (Fig. 4). The ACC deaminase activity was high in all the salt concentrations studied with aggregated cells showing 1.35 to 3.7-folds higher ACC deaminase activity than non-aggregated cells (Fig. 4).

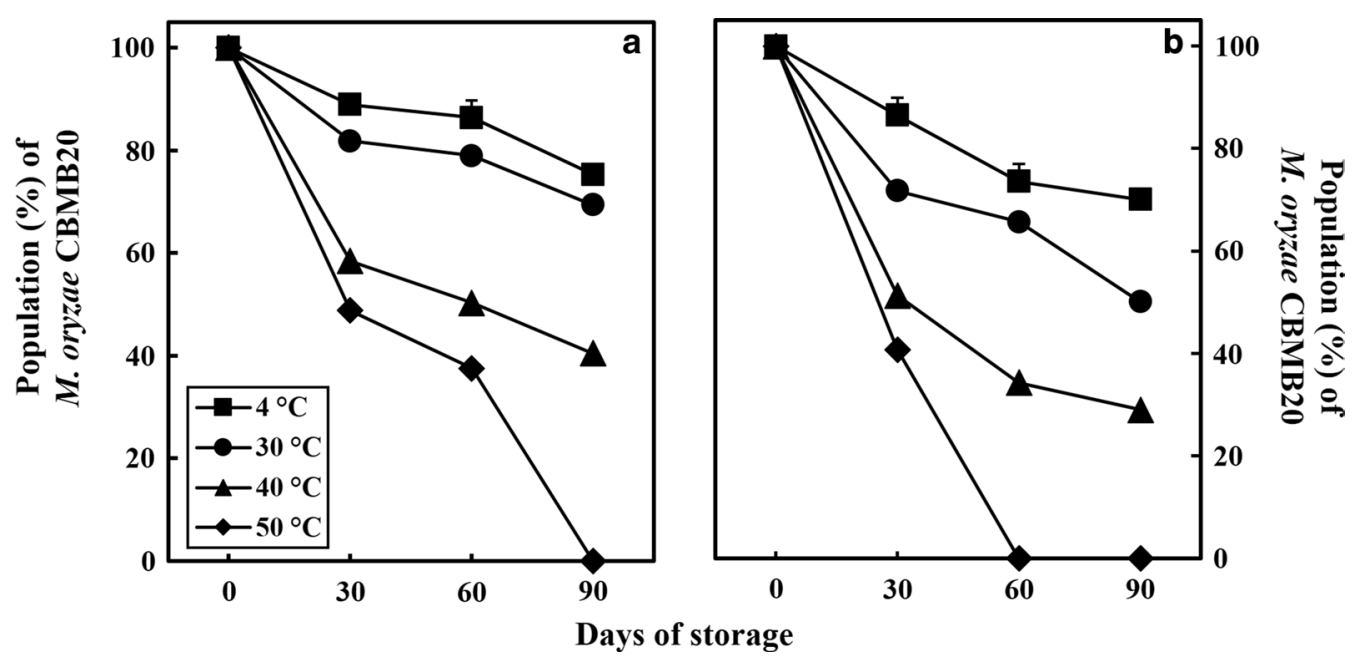

Fig. 2 The impact of a range of temperature on the survival of $\mathbf{a}$ aggregated and $\mathbf{b}$ non-aggregated cells of $M$. oryzae CBMB20. All data represents mean \pm SE of three replicates and differences between means analyzed using DMRT test $(P \leq 0.05)$ 

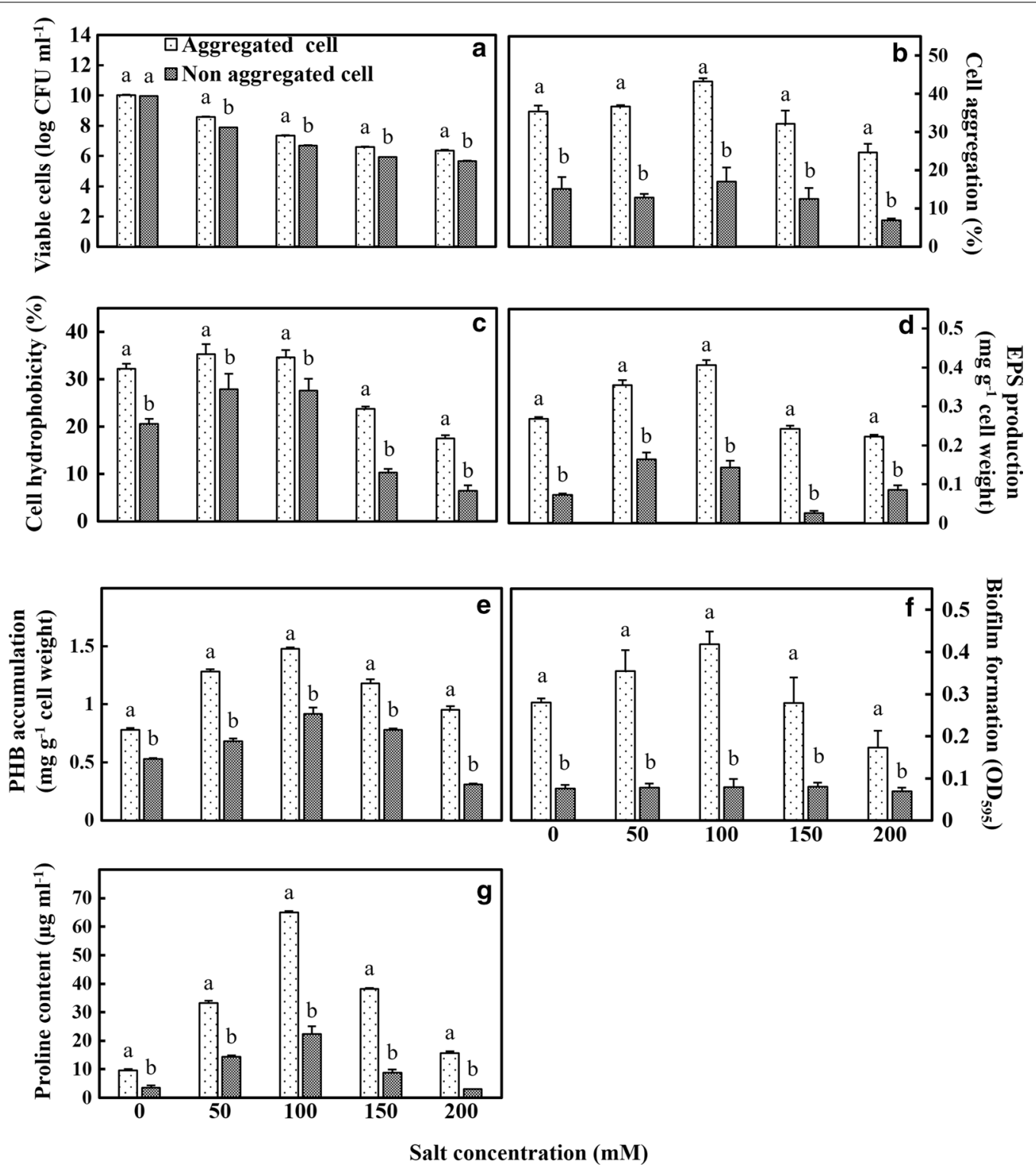

Fig. 3 The impact of different salt concentration on M. oryzae CBMB20 cells. a Survival. b Cell aggregation. c Cell hydrophobicity. d EPS production. e PHB accumulation. $\mathbf{f}$ Biofilm formation and $\mathbf{g}$ Proline accumulation. All data represents mean \pm SE of three replicates and differences between means analyzed using DMRT test $(P \leq 0.05)$

\section{Discussion}

In the present study we studied the aggregation behavior of $M$. oryzae CBMB20 grown in high $\mathrm{C} / \mathrm{N}$ ratio media. Many studies have reported the formation of aggregates and flocs can potentially be utilized in the development of formulations for various agricultural practices (Neyra et al. 1997; Burdman et al. 2000; Bahat-Samet et al. 2004; Joe and Sivakumar 2009). While aggregation of cells is influenced by various chemical and physical factors, nutrient-limited conditions are well known as the major factor to induce aggregation of microorganisms
(Burdman et al. 1998, 2000; Joe and Sivakumar 2009; Rathi et al. 2015).

With nutrient limited conditions mimicking the soil rhizosphere where carbon is rich and nitrogen is limited, soil microorganisms accumulate intracellular food reserve in the form poly hydroxybutyrates (PHB) and produce extracellular polysaccharides (EPS) that helps them survive better under stressed conditions (Kumar et al. 2016; González-García et al. 2015). Studies also suggest that increased extracellular and capsular polysaccharides production facilitate aggregation of $A$. brasilense 

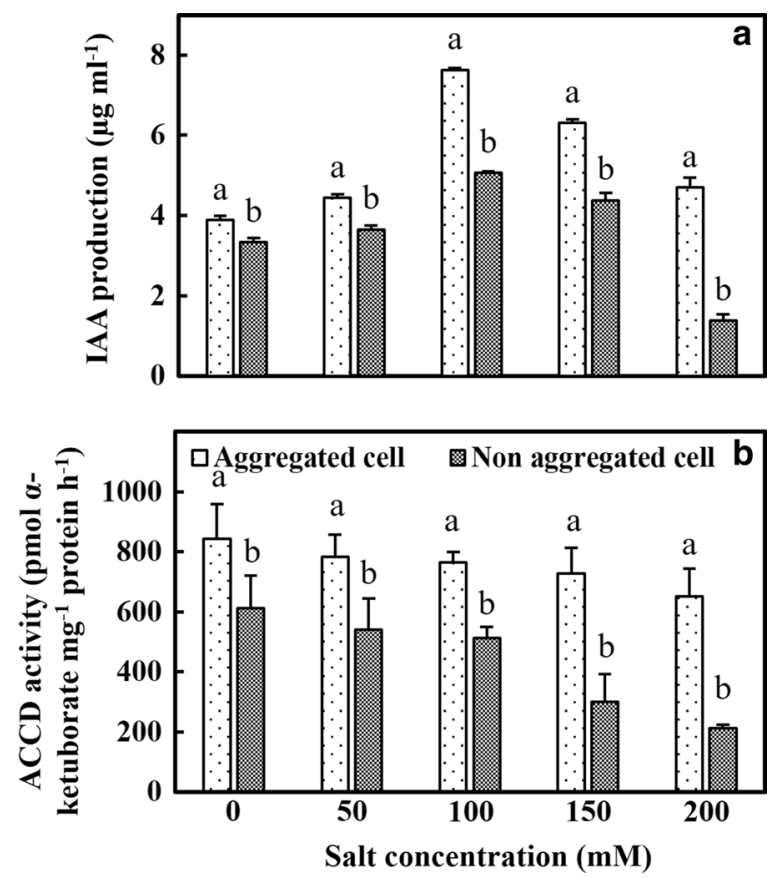

Fig. 4 The impact of different salt concentration on production of plant growth promoting traits of $M$. oryzae CBMB20 cells. a IAA production. b ACC deaminase production. All data represents mean $\pm \mathrm{SE}$ of three replicates and differences between means analyzed using DMRT test $(P \leq 0.05)$ All data represents mean \pm SE of three replicates and differences between means analyzed using DMRT test $(P \leq 0.05)$

cells in high $\mathrm{C} / \mathrm{N}$ ratio medium (Burdman et al. 1998, 2000; Bahat-Samet et al. 2004). The aggregation observed in this study is also linked to the higher EPS production by the aggregated cells. However, the aggregation seems to be a time-dependent mechanism that occurs in cells having a low metabolic activity which is also accompanied by higher hydrophobicity (Bahat-Samet et al. 2004; Joe et al. 2013) which was significantly higher in this study also. Similar observation was made on $M$. oryzae which exhibited a higher level of aggregation, EPS, and PHB content when grown in the modified ammonium minimal salt medium (AMS) at high $\mathrm{C} / \mathrm{N}$ ratio (Woo et al. 2012).

The aggregated cells could withstand UV irradiation, heat, desiccation, different temperature regimes, $\mathrm{H}_{2} \mathrm{O}_{2}$ stress, and starvation with better population growth than non-aggregated cells. Along with this they also showed higher Poly- $\beta$-hydroxybutyrate (PHB) accumulation, exopolysaccharide (EPS) production, proline accumulation and biofilm formation. Ability to accumulate PHB during stress could be attributed to the tolerance at higher temperature. This cannot be ruled out in the enhanced survival of $M$. oryzae CBMB20 aggregates as they are reported to help Azospirillum brasilense,
Aeromonas hydrophila 4AK4, Sinorhizobium meliloti and recombinant $E$. coli to overcome various physico-chemical and environmental stress conditions (Kadouri et al. 2003; Zhao et al. 2007; Ratcliff et al. 2008; Wang et al. 2009). The intracellular PHB serve as energy reservoir during prolonged storage and that may be the possible reason for differential survival of aggregated $M$. oryzae CBMB20 was found at 4 and $30{ }^{\circ} \mathrm{C}$ storage temperature. The possible mechanism behind Poly-hydroxyalkanoates (PHA) accumulation was attributed to the expression of outer membrane proteins (OMPs) under stress conditions (Schweder et al. 1996; Burdman et al. 2000; Alvarez-Ordóñez et al. 2015). In A. brasilense strain Sp7 and S. meliloti the biosynthesis and accumulation of $\mathrm{PHB}$ was reported to help the bacteria survive under competitive environment and further help in root colonization (Kadouri et al. 2003; Ratcliff et al. 2008).

A number of bacteria are reported to adapt to challenging environmental conditions such as osmotic stress. However, this ability to survive and thrive under such conditions depends on the ability of the individual cells to survive the initial and the gradient shock. In general, Methylobacterium sp. cannot grow well under salt stress conditions. Schauer et al. (2011) has conferred that growth of Methylobacterium marchantiae is reduced by $50 \%$ when grown in $0.5 \% \mathrm{NaCl}$ in $\mathrm{R} 2 \mathrm{~A}$ agar. Similar results were shown when Methylobacterium pseudosasicole was grown under $\mathrm{NaCl}$ concentrations of $0-7 \%$ (Madhaiyan and Poonguzhali 2014). While M. oryzae CBMB20 could withstand $\mathrm{NaCl}$ stress, its performance varied according to the $\mathrm{NaCl}$ concentration used. In an earlier study, two methylotrophs viz. Methylophilus sp. and Methylobacterium sp. were reported to grow in the presence of $\mathrm{NaCl}$ with Methylobacterium showing increased enzyme activity even at $500 \mathrm{mM} \mathrm{NaCl}$ concentration (Giri et al. 2013). Performance of aggregated and non-aggregated cells in this study even at $200 \mathrm{mM}$ concentration substantiates the ability of Methylobacterium sp. to withstand higher salt concentrations. Increase in the extracellular polysaccharide (EPS) production up to two to threefolds with an increasing salt concentration till $100 \mathrm{mM} \mathrm{NaCl}$ further strengthens the ability of microbes to produce exopolysaccharides under salt stress. (Lloret et al. 1998). Similar observations were made previously in Rhizobia sp. (Arora et al. 2006) and P. putida CZ1 capable of producing EPS and biofilm providing a hydrated microenvironment to protect the cells from osmotic stress (Lin et al. 2014). Besides this, increase in Proline, the beneficial amino acid, that act as an intracellular osmolyte and protect cells (Paleg et al. 1984) from changing salt concentration up to $100 \mathrm{mM}$ salt concentration observed in this study was also reported in $B$. megaterium and Pseudomonas putida (Marulanda et al. 
2009), Escherichia coli, Pseudomonas aeruginosa and Salmonella typhimurium (Baich 1969; Csonka 1981; Krishna et al. 1979). The differences in Proline accumulation was attributed to the different abilities of the bacterial isolates under osmotic stress conditions (Marulanda et al. 2009).

Production of auxins, an important hormone that activates plant cells division, is widespread among plant growth promoting bacteria and $M$. oryzae CBMB20 is no exception to this. The aggregated cells produced IAA up to $100 \mathrm{mM}$ salinity with a decline at higher concentrations. Though the trend was similar in non-aggregated cells, at $200 \mathrm{mM} \mathrm{NaCl}$ concentration the IAA levels declined drastically indicating the inherent potential of the strain to produce IAA even under stress and the protection offered by the bacterial cell metabolism at high salt stress conditions to continue to produce IAA at higher quantities. The ACC deaminase activity was high in all the salt concentrations studied with aggregated cells registering 1.35- to 3.7-folds higher ACC deaminase activity than non-aggregated cells. Earlier studies also show a number of microbial strains like Alcaligens sp., Bacillus sp., Brachybacterium paraconglomeratum, Ochrobactrum sp., Pseudomonas sp. and Serratia sp. to produce IAA and ACC deamilnase under salt stress (Barnawal et al. 2016; Bal et al. 2013; Glick 2014; Nakbanpote et al. 2014; Marulanda et al. 2009). Upon field application, IAA and ACC deaminase produced by bacteria were reported to stimulate root growth in a coordinated fashion (Glick et al. 2007). As the isolate, $M$. oryzae CBMB20 has the ability to produce both IAA and ACC deaminase the strain could be a potential candidate for further formulation studies both in aggregated and non-aggregated form and use in salt stressed environments.

Hence, use of plant growth promoting rhizobacteria (PGPR) is a promising low cost eco-friendly strategies for mitigating salinity stress management in sustainable agriculture. However, characterizing bacteria for performance against stress would help scientists to understand their behavior for large scale applications. The plant growth promoting bacteria, $M$. oryzae CBMB20 isolated as endophyte of rice plants could form aggregates in media containing high $\mathrm{C} / \mathrm{N}$ ratio (30:1) and the aggregates grew well and withstand UV irradiation, heat, desiccation, different temperature regimes, $\mathrm{H}_{2} \mathrm{O}_{2}$, starvation and grow well in media. The bacteria also produced poly- $\beta$-hydroxybuterate (PHB), exopolysaccharide (EPS), and accumulate proline and form biofilms at $100 \mathrm{mM}$ salt concentration with good microbial cell hydrophobicity. The ability of aggregated form to produce plant growth promoting hormones under salt stress paves way for its use in preparation of polymer based formulation for application in saline agriculture.

\section{Abbreviations}

EPS: exopolysaccharide; PHB: poly- $\beta$-hydroxybuterate; ACC:

1-aminocyclopropane-1-carboxylate.

\section{Authors' contributions}

MC, GHH amd TS designed the experiments; MC and GHH conducted the experiments; YK assisted in conducting few experiments; MC, GHH, AR, SS and TS analyzed the data and wrote the manuscript; MAH and RK conducted critical reviews and helped in writing the manuscript. All authors read and approved the final manuscript.

\section{Author details}

${ }^{1}$ Department of Environmental and Biological Chemistry, College of Agriculture, Life and Environment Sciences, Chungbuk National University, Cheongju, Chungbuk 361-763, Republic of Korea. ${ }^{2}$ Indegenous and Frontiers Technology Research (IFTR) Centre, Chennai, India. ${ }^{3}$ Tamil Nadu Agricultural University, Madurai, India.

\section{Acknowledgements}

Not applicable.

\section{Competing interests}

The authors declare that they have no competing interests.

\section{Availability of data and materials}

All data are shown in Figures and Tables within this article. Any material used in this study is available for research purposes upon request.

\section{Consent for publication}

Not applicable.

\section{Ethics approval and consent to participate}

This article does not contain any studies with human participants or animals performed by any of the authors.

\section{Funding}

This study was supported by Basic Science Research Program through the National Research Foundation (NRF) funded by the Ministry of Education, Science and Technology (2015R1A2A1A05001885), Republic of Korea.

\section{Publisher's Note}

Springer Nature remains neutral with regard to jurisdictional claims in published maps and institutional affiliations.

Received: 5 October 2017 Accepted: 15 November 2017

Published online: 21 November 2017

\section{References}

Albalasmeh AA, Berhe AA, Ghezzehei TA (2013) A new method for rapid determination of carbohydrate and total carbon concentrations using UV spectrophotometry. Carbohydr Polym 97(2):253-261

Alvarez-Ordóñez A, Broussolle V, Colin P, Nguyen-The C, Prieto M (2015) The adaptive response of bacterial food-borne pathogens in the environment, host and food: implications for food safety. Int J Food Microbiol 213:99-109

Arora NK, Singhal V, Maheshwari DK (2006) Salinity-induced accumulation of poly- $\beta$-hydroxybutyrate in rhizobia indicating its role in cell protection. World J Microbiol Biotechnol 22:603-606

Bahat-Samet E Castro-Sowinski S, Okon Y (2004) Arabinose content of extracellular polysaccharide plays a role in cell aggregation of Azospirillum brasilense. FEMS Microbiol Lett 237:195-203

Baich A (1969) Proline synthesis in Escherichia coli a proline-inhibitable glutamic acid kinase. Biochim Biophys Acta 192:462-467 
Bal HB, Nayak L, Das S, Adhya TK (2013) Isolation of ACC deaminase producing PGPR from rice rhizosphere and evaluating their plant growth promoting activity under salt stress. Plant Soil 366:93-105

Bano N, Musarrat J (2003) Characterization of a new Pseudomonas aeruginosa strain NJ-15 as a potential biocontrol agent. Curr Microbiol 46:324-328

Barnawal D, Bharti N, Tripathi A, Pandey SS, Chanotiya CS, Kalra A (2016) ACCdeaminase-producing endophyte Brachybacterium paraconglomeratum strain SMR20 ameliorates Chlorophytum salinity stress via altering phytohormone generation. Plant Growth Regul 35:553-564

Bashan Y, de-Bashan LE, Prabhu SR, Hernandez JP (2014) Advances in plant growth-promoting bacterial inoculant technology: formulations and practical perspectives (1998-2013). Plant Soil 378:1-33

Bates LS, Waldren RP, Teare ID (1973) Rapid determination of free proline for water-stress studies. Plant Soil 39:205-207

Burdman S, Jurkevitch E, Schwartsburd B, Hampel M, Okon Y (1998) Aggregation in Azospirillum brasilense: effects of chemical and physical factors and involvement of extracellular components. Microbiology 144:1989-1999

Burdman S, Jurkevitch E, Soria-Díaz ME, Serrano AMG, Okon Y (2000) Extracellular polysaccharide composition of Azospirillum brasilense and its relation with cell aggregation. FEMS Microbiol Lett 189:259-264

Catroux G, Hartmann A, Revellin C (2001) Trends in rhizobial inoculant production and use. Plant Soil 230:21-30

Csonka LN (1981) Proline over-production results in enhanced osmotolerance in Salmonella typhimurium. Mol Gen Genet 182:82-86

Djordjevic D, Wiedmann M, McLandsborough LA (2002) Microtiter plate assay for assessment of Listeria monocytogenes biofilm formation. Appl Environ Microbiol 68:2950-2958

Giri DD, Kumar A, Shukla PN, Singh RITU, Singh PK, Pandey KD (2013) Salt stress tolerance of methylotrophic bacteria Methylophilus sp. and Methylobacterium sp. isolated from coal mine spoils. Pol J Microbiol 62:273-280

Glick BR (2012) Plant growth-promoting bacteria: mechanisms and applications. Scientifica 2012:1-15

Glick BR (2014) Bacteria with ACC deaminase can promote plant growth and help to feed the world. Microbiol Res 169:30-39

Glick BR, Todorovic B, Czarny J, Cheng Z, Duan J, McConkey B (2007) Promotion of plant growth by bacterial ACC deaminase. CRC Crit Rev Plant Sci 26:227-242

González-García Y, Heredia A, Meza-Contreras JC, Escalante FME, CamachoRuiz RM, Córdova J (2015) Biosynthesis of extracellular polymeric substances by the marine bacterium Saccharophagus degradansunder different nutritional conditions. Int J Polym Sci 2015:1-7

González-Pastor JE (2011) Cannibalism: a social behavior in sporulating Bacillus subtilis. FEMS Microbiol Rev 35:415-424

Grimaudo NJ, Nesbitt WE (1997) Coaggregation of Candida albicans with oral Fusobacterium species. Mol Oral Microbiol 12:168-173

Idris R, Trifonova R, Puschenreiter M, Wenzel WW, Sessitsch A (2004) Bacterial communities associated with flowering plants of the Ni hyperaccumulator Thlaspi goesingense. Appl Environ Microbiol 70:2667-2677

Joe MM, Sivakumar PK (2009) Role of certain cationic compounds on the enhancement of flocculation in Azospirillum brasilense MTCC-125: bioinoculation effect on growth of sunflower. Die Bodenkultur 5:4

Joe M, Karthikeyan MB, Sekar C, Deiveekasundaram M (2010) Optimization of biofloc production in Azospirillum brasilense (MTCC-125) and evaluation of its adherence with the roots of certain crops. Indian J Microbiol 50:21-25

Joe MM, Islam MR, Karthikeyan B, Bradeepa K, Sivakumaar PK, Sa T (2012) Resistance responses of rice to rice blast fungus after seed treatment with the endophytic Achromobacter xylosoxidans AUM54 strains. Crop Prot 42:141-148

Joe MM, Saravanan VS, Sa T (2013) Aggregation of selected plant growth promoting Methylobacterium strains: role of cell surface components and hydrophobicity. Arch Microbiol 195:219-225

Kadouri D, Jurkevitch E, Okon Y (2003) Involvement of the reserve material poly- $\beta$-hydroxybutyrate in Azospirillum brasilense stress endurance and root colonization. Appl Environ Microbiol 69:3244-3250

Kadouri D, Jurkevitch E, Okon Y, Castro-Sowinski S (2005) Ecological and agricultural significance of bacterial polyhydroxyalkanoates. Crit Rev Microbiol 31:55-67

Krishna RV, Beilstein P, Leisinger T (1979) Biosynthesis of proline in Pseudomonas aeruginosa. Properties of glutamyl phosphate reductase and 1-pyrroline-5-carboxylate reductase. Biochem J 181:223-230
Kumar P, Singh M, Mehariya S, Patel SK, Lee JK, Kalia VC (2014) Ecobiotechnological approach for exploiting the abilities of Bacillus to produce co-polymer of polyhydroxyalkanoate. Indian J Microbiol 54:151-157

Kumar P, Ray S, Kalia VC (2016) Production of co-polymers of polyhydroxyalkanoates by regulating the hydrolysis of biowastes. Bioresour Technol 200:413-419

Li Z, Chang S, Lin L, LiY, An Q (2011) A colorimetric assay of 1-aminocyclopropane-1-carboxylate (ACC) based on ninhydrin reaction for rapid screening of bacteria containing ACC deaminase. Lett Appl Microbiol 53:178-185

Lin H, Chen G, Long D, Chen X (2014) Responses of unsaturated Pseudomonas putida CZ1 biofilms to environmental stresses in relation to the EPS composition and surface morphology. World J Microbiol Biotechnol 30:3081-3090

Lloret J, Wulff BB, Rubio JM, Downie JA, Bonilla I, Rivilla R (1998) Exopolysaccharide II Production Is Regulated by Salt in the Halotolerant Strain Rhizobium meliloti EFB1. Appl Environ Microbiol 64:1024-1028

Madhaiyan M, Poonguzhali S (2014) Methylobacterium pseudosasicola sp. nov. and Methylobacterium phyllostachyos sp. nov., isolated from bamboo leaf surfaces. Int J Syst Evol Microbiol 64:2376-2384

Madhaiyan M, Poonguzhali S, Kwon SW, Sa TM (2009) Methylobacterium phyllosphaerae sp. nov., a pink-pigmented, facultative methylotroph from the phyllosphere of rice. Int J Syst Evol Microbiol 59:22-27

Maheshwari DK (Ed.) (2012) Bacteria in agrobiology: stress management. Springer Science and Business Media, p 27-40

Mahipant G, Paemanee A, Roytrakul S, Kato J, Vangnai AS (2017) The significance of proline and glutamate on butanol chaotropic stress in Bacillus subtilis 168. Biotechnol Biofuels 10(1):122

Marulanda A, Barea JM, Azcón R (2009) Stimulation of plant growth and drought tolerance by native microorganisms (AM fungi and bacteria) from dry environments: mechanisms related to bacterial effectiveness. J Plant Growth Regul 28:115-124

Merritt JH, Kadouri DE, O'Toole GA (2005) Growing and analyzing static biofilms. In: Coico R, Kowalik T, Quarles J, Stevenson B, Taylor R (eds) Current protocols in microbiology. Wiley, Hoboken

Nakbanpote W, Panitlurtumpai N, Sangdee A, Sakulpone N, Sirisom P, Pimthong A (2014) Salt-tolerant and plant growth-promoting bacteria isolated from $\mathrm{Zn} / \mathrm{Cd}$ contaminated soil: identification and effect on rice under saline conditions. J Plant Interact 9:379-387

Neyra CA, Arunakumari A, Olubayi O (1997) Flocculated microbial inoculants for delivery of agriculturally beneficial microorganisms. U.S. Patent Number $5,697,186$. U.S. Patent and trademark office, Washington

Omer ZS, Tombolini R, Gerhardson B (2004) Plant colonization by pinkpigmented facultative methylotrophic bacteria (PPFMs). FEMS Microbiol Ecol 47:319-326

Paleg LG, Stewart GR, Bradbeer JW (1984) Proline and glycine betaine influence protein solvation. J Plant Physiol 75:974-978

Penrose DM, Glick BR (2003) Methods for isolating and characterizing ACC deaminase-containing plant growth-promoting rhizobacteria. Physiol Plant 118:10-15

Perpetuini G, Tittarelli F, Schirone M, Di Gianvito P, Corsetti A, Arfelli G, Tofalo R (2017) Adhesion properties and surface hydrophobicity of Pichia manshurica strains isolated from organic wines. LWT Food Sci Technol 87:385-392

Ratcliff WC, Kadam SV, Denison RF (2008) Poly-3-hydroxybutyrate (PHB) supports survival and reproduction in starving rhizobia. FEMS Microbiol Ecol 65:391-399

Rathi N, Singh S, Osbone J, Babu S (2015) Co-aggregation of Pseudomonas fluorescens and Bacillus subtilis in culture and co-colonization in black gram (Vigna mungo L.) roots. Biocat Agric Biotechnol 4:304-308

Sandhya V, Ali SZ, Grover M, Reddy G, Venkateswarlu B (2010) Effect of plant growth promoting Pseudomonas spp. on compatible solutes, antioxidant status and plant growth of maize under drought stress. Plant Growth Regul 62:21-30

Schauer S, Kämpfer P, Wellner S, Spröer C, Kutschera U (2011) Methylobacterium marchantiae sp. nov., a pink-pigmented, facultatively methylotrophic bacterium isolated from the thallus of a liverwort. Int I Syst Evol Microbiol 61:870-876

Schweder T, Lee KH, Lomovskaya O, Matin A (1996) Regulation of Escherichia coli starvation sigma factor by ClpXP protease. J Bacteriol 178:470-476

Sharma DK, Chaudhari SK (2012) Agronomic research in salt affected soils of India: an overview. Indian J Agron 57:175-185 
Souza RD, Ambrosini A, Passaglia LM (2015) Plant growth-promoting bacteria as inoculants in agricultural soils. Genet Mol Biol 38:401-419

Wang Q, Yu H, Xia Y, Kang Z, Qi Q (2009) Complete PHB mobilization in Escherichia coli enhances the stress tolerance: a potential biotechnological application. Microb Cell Fact 8:47

Whipps J, Hand P, Pink D, Bending GD (2008) Phyllosphere microbiology with special reference to diversity and plant genotype. J Appl Microbiol 105:1744-1755
Woo SM, Subramanian P, Ramasamy K, Joe MM, Sa TM (2012) EPS production, PHB accumulation and abiotic stress endurance of plant growth promoting Methylobacterium strains grown in a high carbon concentration. Korean J Soil Sci Fert 45:572-581

Zhao YH, Li HM, Qin LF, Wang HH, Chen GQ (2007) Disruption of the polyhydroxyalkanoate synthase gene in Aeromonas hydrophila reduces its survival ability under stress conditions. FEMS Microbiol Lett 276:34-41

\section{Submit your manuscript to a SpringerOpen ${ }^{\circ}$ journal and benefit from:}

- Convenient online submission

- Rigorous peer review

- Open access: articles freely available online

- High visibility within the field

- Retaining the copyright to your article

Submit your next manuscript at $\boldsymbol{\nabla}$ springeropen.com 